International Journal of Biology, Pharmacy and Allied Seiences (IJBPAS) 'A Bridge Betuen Caboratory and Qnendo'

Www.ijbpas.com

\title{
A REVIEW ON MILK ADULTERATION AND LACTIC ACID BACTERIA FROM MILK SAMPLES
}

\section{RAICHANDANI $M^{1}$, UPADHAYAY $D^{2}$, ANDHARE $P^{2}$ AND PRAJAPATI ${ }^{2 *}$}

1: PG student M.sc (Microbiology), Department of Microbiology, Parul Institute of Applied Science, Parul University, Po-Limda 391760, Ta- Waghodia, Dis- Vadodara

2: Assistant Professor, Department of Microbiology, Parul Institute of Applied Science, Parul University, Po-Limda 391760, Ta- Waghodia, Dis- Vadodara

*Corresponding Author: Dr. Priyanka Prajapati; E Mail: priyanka.mistry82141@paruluniversity.ac.in; Tel:

$+919913562946$

Received 22 ${ }^{\text {nd }}$ Jan. 2021; Revised 24 ${ }^{\text {th }}$ Feb. 2021; Accepted $25^{\text {th }}$ March 2021; Available online $1^{\text {st }}$ April 2021 https://doi.org/10.31032/IJBPAS/2021/10.4.1043

ABSTRACT

Milk is the major sources of Lactic acid bacteria. Mainly Lactobacillus is found in milk. Milk becomes important sources for diet for newborn and mammals. Mainly raw cow milk is good sources of lactic acid bacteria. They are gram positive, non-sporulating, facultative anaerobe and varied from cocci to rod. They are naturally found in dairy products and fermented products. It is also used in bakery products. Many lactic acid species are used for increasing shelf life of products. Milk adulteration is one of the techniques from which the quality of the milk can be verified. Qualitative adulteration is the simplest and rapid detection of adulterants such as hydroden peroxide, ammonium sulphate, detergents, sugar and glucose.

Keywords: Cow milk, Buffalo milk, Lactic acid bacteria, Milk adulteration

\section{INTRODUCTION}

Milk is important nutritious part in our daily diet. Major components in milk are namely water, fat, lactose, proteins, minerals etc. The composition of these components differs on the basis of types of milk. The major reason of this differentiation could be the physiological, genetical and nutritional factor condition. Environmental conditions also play crucial role in this differentiation [1]. 
Apart from minerals and main components milk also contains adulterants such as boric acid, formaldehyde, starch, sodium chloride, nitrates, nutilizers etc. Not only just chemicals and components, milk also contains naturally occurring bacteria mostly lactic acid bacteria (LAB) [1]. Generally lactic acid bacteria are present in habitat rich in nutrients like milk, cheese, meat, beverages and vegetables [2]. In addition, it is also shown that LAB can also be isolated from soil, lakes and also from human and animal intestine. $L A B$ is used for food fermentation since ancient times and nowadays it is more likely used as starter culture in food and feed factories [3]. LAB is also being answerable for fermentation of bread, also used to ferment milk, beverages and fermented vegetables [4]. It also plays major role in glucose fermentation process. Based on the type of fermentation LAB is classified into two types namely homofermenters and heterofermenter. Homofermenter produce lactic acid bacteria as major product of glucose fermentation while heterofermenter lactic acid, carbon dioxide, acetic acid as the products of glucose fermentation [5].

The very first known and studied bacteria were LAB. It was first isolated by Joseph Lister in 1873 from bacterial pure culture and was named as Bacterium Lactis but nowadays they are known as Lactococcus. There were seven genera of LAB found by Orla Jensen in 1919 from which only one of them is valid till now which is Streptococcus [6].

According to the classification done in 2018 LAB comes under phylum Firmicutes, class Bacilli, and order Lactobacillales. It consist of various different genera but the major genera includes Lactobacillus, Lactococcus, Weissella, Pediococcus, Enterococcus, Streptococcus etc. Till now LAB consist of 16 genera and among them 12 genera have remarkable consideration with food fermentation [7]. Lactic acid bacteria (LAB) are a group of Gram- positive, nonsporulating, anaerobic or facultative aerobic cocci or rods, and produce lactic acid as major fermentation products of the metabolism of carbohydrates. They are naturally produces in milk and milk products. Most of the species are non-motile [7].

\section{MILK ADULTERATION}

Adulteration of milk is also important to know the quality of milk and milk products. It is used to cover the quality parameters and rise the product shelf life. In order to guarantee the food safety and escape health risks to consumers, novel analytical procedures have been planned for finding of 
these additives. Qualitative adulteration of milk was done and quality of milk samples was detected [8]. They are the color based chemical reaction of milk and milk products. However, the advantages of qualitative adulteration is that they are simple, easy and rapid. Few edible elements are also added to improve the flavor of milk. Milk and foodstuff adulteration came into international concern when breakthrough of base contamination in Chinese child milk product in 2008. However, olden times of milk infection is extraordinarily recent. Swill milk repute has been informed in 1850 that killed 8000 infants. Milk is taken under consideration to be the 'ideal food' owing to its well-endowed nutrients needed by each infants and adults. It is one in all the only sources for supermolecule, fat, saccharide, vitamin and minerals[9].Adulterants in milk chiefly embody addition of vegetable protein, milk from fully completely different species, addition of whey and watering that unit of measurement known as economically driven adulteration [10].

Mostly known parameters that are clarified and can determine the milk value are fat percentage, solid-Not-Fat, protein content and freezing point. The proportion of adulterants are increased to upsurge the milk quality which is not the right way. Like sugar, salts, starch are additional to increase the SNF value. Uric acid is supplementary to rise the value of non- protein nitrogen content. Preservatives such as formalin is added to increase the shelf life of milk [11].

Based on type of adulterants they are categorized into two types: Qualitative adulteration and Quantitative adulteration. Quantitative adulteration are time taking and used to regulate the total SNF and protein contented of the milk. Qualitative adulteration is color-based reaction and easy to carry out [12]. It is used to define the presence and absence of adulterants which can be useful and also be harmful when increase its amount. Adulterants such as ammonium sulphate, hydrogen peroxide, formalin, boric acid can be detected from this method [13].

MBRT can also be can also be one of the test to check the superiority of milk. MBRT is east and quick test and it is done to check the quality of milk. MBRT stands for Methylene Blue Dye Reduction test. This test is based on decolorization of milk when oxygen in milk get exhausted due to microbial activity [14]. Methylene blue dye is auxiliary to milk and decolorization time is recorded to check the quality of milk samples. Sooner the decolorization bad is the quality of milk which means more infectious is be the milk. Here is the tabale which shows the time taken by diverse milk samples to get decolorization [15]. 
Table 1: Milk quality through MBRT test [15]

\begin{tabular}{|c|c|c|}
\hline S. No. & Milk quality & Time of reduction \\
\hline 1 & Very poor & 30 mins \\
\hline 2 & poor & 30 mins-2 hrs. \\
\hline 3 & good & $2-6$ hrs. \\
\hline 4 & Very good & $6-8$ hrs. \\
\hline 5 & excellent & More than 8 hrs. \\
\hline
\end{tabular}

\section{ADVANTAGES OF LACTIC ACID BACTERIA}

There are many potential health or organic advantages attainable from some classes of acid bacterium. Among these are: improved organic process worth of food, management of internal infections, improved digestion of disaccharide, management of some varieties of cancer, and management of bodily fluid steroid alcohol levels [16, 17]. Some potential advantages might produce from growth and action of the bacterium throughout the production of civilized foods. Some might result from growth and action of some species of the acid bacterium inside the enteral tract following intake of foods comprising them. In choosing a culture to yield a selected profit it's necessary to believe not solely the extensive deviation amongst species of the acid bacterium however additionally that among strains inside a particular species [18].

\section{DISADVANTAGES LACTIC ACID} BACTERIA

Anaerobic respiration generates solely 2 ATPs and produces carboxylic acid. Most carboxylic acid diffuses out from the cell and into the blood and is afterwards absorbed by the liver [19]. A number of the carboxylic acid remains within the muscle fibers, wherever it contributes to muscle fatigue. While exercise, the liver and muscles ought to convert the carboxylic acid back to acid. This can be called "repaying the debt," thence the term "oxygen debt."[20]

\section{DIFFERENT USES OF LACTIC ACID BACTERIA}

They ferment food carbohydrates and produce carboxylic acid as the main product of fermentation. Furthermore previously, for degradation of proteins and lipids and production of varied alcohols, aldehydes, acids, esters and sulphur compounds are used for flavor development in several fermented food products. Fermented foods are produced by fermentation of sugars by LAB and so the origins of them are lost in antiquity. The majorly LAB used as starter cultures in food fermentation industry. The majority of them belong to the category of dairy products, like cheese, yoghurt, fermented milks, while fermented meat products, fish products, pickled vegetables and olives and an excellent sort of cereal products are 
manufactured, nowadays, using starter cultures [21]. They were produced within the past through back slopping and resulting product characteristics trusted the bestadapted strains dominance, whereas, the earliest productions of them were supported the spontaneous fermentation, resulting from the event of the micro flora naturally present within the staple and its environment [22]. Today, the bulk of fermented foods are manufactured with the addition of selected, well defined, starter cultures with well characterized traits, specific for every individual product [23].

Certain LAB has been found to produce bacteriocins, namely, polypeptides synthesized ribosomally by bacteria. Useful bacteriocins produced by LAB are lactic in from Lactococci, macedovicin and Streptococcus macedonicus [24]. The above bacteriocins have proved effective in many food systems for the control of food spoilage or in addition; LAB strains also have the ability to reduce fungal mycotoxins, through producing anti-fungal metabolites, or by absorbing the pathogenic bacteria [25]. LAB have very important role in agriculture as well. LAB have very effective response at improving pore space in soil/soil ventilation. They increase the solubility of fertilizers [26, 27].

\section{CONCLUSION}

From this review it can concluded that the abundant population of lactic acid bacteria is observed not only in fermented foods but also in dairy products. It can be concluded that the lactic acid bacteria not fermented food but also in dairy. The involved LAB is Lactococci, Lactococcus and Streptococcus. It can be concluded from the review that the lactic acid bacteria play both positive and negative role as there are certain disadvantages and some of the advantages for which they are highly used for various purpose. Adulteration of milk is important to know the quality of milk.

\section{ACKNOWLDGEMENT}

It's our privilege and honour to express our sincerest gratitude to the Parul University, Vadodara, Gujarat for providing me all the necessary support and facilities including state of the art infrastructural facilities with advanced technological scientific laboratories and everything else that was required to carry out this work.

\section{REFERENCES}

[1] Boonmee M, Leksawasdi N, Bridge $\mathrm{W}$ et al:"Batch and continuous culture of Lactococcus lactic NZ133”. Experimental data and model development. Biochem. Eng. J. May 2003; 14(2): 127-135. 
[2] Chen Y.S, Yangida F, Shinahara $\mathrm{T}$ :"Isolation and identification of lactic acid bacteria, from soil using enrichment procedure". Applied Microbiol. March2005; 40(3): 195200.

[3] Dezmons S, Krhouz H, Evrard P, Thonart P: "Improvement of lactic acid cell production". Applied Biochem. Biotechnol. July 1998; 7072(1): 513-26.

[4] Sharma RSR, Barui AK, Ed et al: "Rapid Methods for Detection of Adulterants in Milk Chemical analysis of value-added dairy products and their quality assurance". National Dairy Research Institute. Dec 2011; 7(1): 2056-2058.

[5] Steele J, Broadbent J, Kok J: "Perspective on the Contribution of Lactic Acid Bacteria to Cheese Flavor Development." Current Opinion in Biotechnology. Dec 2013: 24(2); 135141.

[6] Tserovska L, Stefanova S, Yordanovu $\mathrm{T}$ : "Identification of lactic acid bacteria isolated from katyk, goat. Milk and cheese. J. Culture Collections." National Bank for Industrial Microorganism and Cell Cultures. Jun 2002; 3(1): 48-52.
[7] Axelson L: "Lactic Acid Bacteria: Classification and physiology." Lactic Acid Bacteria, Microbiological and Functional Aspects. Salinan, A.V. and A.O. Wright (Eds.) cowhand. Marcel Dekker, New York. Dec 2004; 3(1): 1-6.

[8] Arvind Singh GC, Aggarwal A, Kumar $\mathrm{P}$ et al: "Adulteration Detection in Milk". Res News for U (RNFU). Jan 2012; 5(1): 52-56.

[9] Bidis A, Guarani D, Moussa-Oedema B, Henna D, Tornado M and Kahala M: "Identification of cultivable lactic acid bacteria isolated from Algerian raw goat's milk and evaluation of their technological properties". Food Microbiol. June 2021; 21(3): 343349.

[10] Bard J.M, Drouet L, Lairon D, Cazaubiel, M.; Marmonier, C. et al: "Effect of milk fat on LDL cholesterol and other cardiovascular risk markers in healthy humans" The innovalait project. Eur. J. Clin. Nutr. Nov 2020; 74(1): 285-296.

[11] Canchaya C, Claesson M. J., Fitzgerald G. F., Van Sinderen, D et al: "Diversity of the genus Lactobacillus revealed by comparative Klanomics of five 
species". Microbiology. Nov 2006; 152(11): 3185-3196.

[12] DE Souza EMT, Arruda SF, Brandao PO, Siqueira EM, Almeida D: "Electrophoretic analysis to detect and quantify additional whey in milk and dairy beverages". Ciênc Tecnol Aliment. Dec 2000; 20(3): 314-7.

[13] Delavenne E, Mounier J, Déniel F, Barbier G, Le Blay G: "Biodiversity of Antifungal Lactic Acid Bacteria Isolated from Raw Milk Samples from Cow, Ewe and Goat over OneYear Period." International Journal of Food Microbiology. April 2012; 155(3): 185-190.

[14] Gantner V, Mirjana Baban et.al: "The overall and fat composition of milk of various species." Mljekarstvo. Oct 2015; 65(4): 223 231.

[15] Ghodekar DR, Dudani AJ, Ranganathan B: "Microbiological quality of Indian milk products. "Milk Food Technol. March 1974; 37(3): 119-122.

[16] Harrigan W. F, McCance M. E;" Laboratory Methods in Food and Dairy Microbiology." Academic
Press, London. Jan 1976; Vol 3(8): 25-29.

[17] Holt J, Krieg R, Senath A, Staley T, Williams S: "Bergey's manual of determinative bacteriology." Hensly RW and Forlifer E L (eds). 9th ed. Williams and Wilkins. Baltirnore, USA. Dec 1994; 2(2) :787.

[18] Holzapfel E. H, Schillinger V, The Genus Leuconostoc. The Prokaryotes, Barlows A., H.G. Truper, M. Dworkin, W. Harder and K. H. Schleifer (Eds.) et al: Springer Publishing, Berlin; Nov 1992; 3(11): 1509-1534.

[19] Holzapfel E. H, Haberer P, Geisen R, Björkroth J, Schillinger U:"Taxonomy and important features of probiotic microorganisms in food and nutrition." American Journal of Clinical Nutrition. Dec 2001; 73(2): 365-373.

[20] Holzapfel E.H, Haberer P, Snel J, Bjorkroth J, Schillinger U, Huis int Veld J. H: "Overview of gut flora and probiotics," International Journal of Food Microbiology. May 1998; 41 (2): 85-100.

[21] Narvhus J.A., AxelssonL: "Encyclopedia of Food Sciences and 
Nutrition (Second Edition)," Jan 2003;6(1):21-29.

[22] Katherina M, Saxena J, Saxena K, Sharma DK: "Methods of Detection \& Remedial Measures". Oct 2014; 1(1): 15-20.

[23] Kavita P: "Studies on the levels of urea in milk Karnal". NDRI. Sep 2000; 22(1): 1-8.

[24] Kebede A: "Isolation, characterization and identification of lactic acid bacteria involved in traditional fermentation of borde, an Ethiopian cereal beverage." African Journal of
Biotechnology. June 2007; 6(12): 1469- 1478.

[25] Kumar A, Lal D, Seth R, Sharma R. "Recent trends in detection of adulteration in milk fat a review". Indian J Dairy Sci.Jan 2002; 55(6) :319-30.

[26] Malacarne. M, Martuzzi. F, Summer. A, Mariani, P: "Protein and fat composition of mare's milk Some nutritional remarks with reference to human and cow's milk." Int. Dairy J. July 2002; 12(1): 869-877. 